\title{
REALITAS POLITIK INDONESIA DALAM "KACAMATA" PENGGUNA TWITTER
}

\author{
S. Kunto Adi Wibowo, Ira Mirawati \\ Departemen Ilmu Manajemen Komunikasi, Fakultas Ilmu Komunikasi, Universitas Padjadjaran
}

\begin{abstract}
ABSTRAK
Twitter sebagai media baru mulai menunjukkan keperkasaannya di bidang politik. Bukti nyata peran besar twitter dalam dunia politik adalah gejolak politik dan sosial di kawasan Timur Tengah yang melanda seluruh negara Arab. Rakyat terpanggil dan tersatukan haluan serta geraknya melalui jejaring sosial digital untuk menentukan jalannya masa depan negara mereka. Penting untuk diketahui pengaruh pandangan tentang politik padapengguna twitter di Indonesia, sebagai Negara dengan pengguna twitter terbanyak. Dengan metode survei yang berpedoman pada teori kultivasi, penelitian ini mencari tahu bagaimana pandangan politik di Indonesia pada pengguna berat dan pengguna ringan.Hasilnya menunjukkan bahwa tidak ada perbedaan signifikan pada pengguna berat dan pengguna ringan dalam memandang politik di Indonesia. Metode survey online dilakukan terhadap tiga puluh enam responden. Mereka ragu akan masa depan Indonesia yang lebih baik, dan tidak percaya bahwa kasus korupsi akan dapat diselesaikan, bahkan pengguna ringan ternyata lebih negatif dalam memandang realitas politik Indonesia. Kondisi ini tidak terlepas dari fakta bahwa twitter bukan sumber utama berita politik mereka. Sumber informasi utama mereka tetap media konvensional, terutama televisi.
\end{abstract}

Kata-kata kunci: Realitas politik, jejaring sosial, teori kultivasi, twitter, media sosial

\section{POLITICAL REALITY OF INDONESIA IN THE POINT OF VIEW OF TWITTER USERS}

\begin{abstract}
Twitter has become a powerful new media in the political area. The example of contribution of twitter in the political scene is the rise of political and social turmoil in the Middle East. By using the social media, people were being called and coordinated to determine their country's destiny in the future. It becomes more important to observe how the Twitter affecting the political perception inIndonesia, the largest country interm of twitter users. By employing survey method based on cultivation theory, this research intend to discoverthe political view for heavy users and light users of social media in Indonesian context. The result shows that there are no significant differences between heavy and light users' perspective on Indonesian politic. Online survey method was employed to the thirty six respondents. The respondents declare that they are not at all confident aboutthe better future of Indonesia. The respondents also do not believe that the corruption cases in Indonesia would be resolved in the near future and the light users has more negative views on Indonesian politics. This condition resulted from the fact that Twitter is not their main source of information on the political issues. The conventional mass media, especially television is still their main information source for political issues.
\end{abstract}

Keywords: Political reality, social network, cultivation theory, twitter, social media

Korespondensi: S. Kunto Adi W, S. Sos., M.Comn., Departemen Ilmu Manajemen Komunikasi, Fakultas Ilmu Komunikasi, Universitas Padjadjaran, Jl. Raya Bandung-Sumedang Km.21. Email: kuntoadi@gmail. com 


\section{PENDAHULUAN}

Twitter, salah satu jejaring sosial di dunia maya, semakin menunjukkan eksistensinya sebagai media berkomunikasi penduduk dunia. Baru-baru ini, tepatnya pada Maret 2011, Comscore.Inc sebagai lembaga peneliti terdepan untuk digital world dan digital marketing intelligence merilis angka pengguna twitter menunjukkan Indonesia sebagai pengguna terbanyak ke-4 setelah Belanda, Brazil, dan Jepang.

Tabel 1 Top 10 Negara Pengguna Twitter dalam \%

\begin{tabular}{lll}
\hline No & Twitter.com & \% Reach \\
\hline 1 & Netherlands & $26.8 \%$ \\
2 & Japan & $26.6 \%$ \\
3 & Brazil & $23.7 \%$ \\
4 & Indonesia & $22.0 \%$ \\
5 & Venezuela & $21.0 \%$ \\
6 & Canada & $18.0 \%$ \\
7 & Argentina & $18.0 \%$ \\
8 & Turkey & $16.6 \%$ \\
9 & Philippines & $16.1 \%$ \\
10 & Singapore & $16.0 \%$ \\
\hline
\end{tabular}

Sumber: Comscore Media Metrix (Comscore, 2011)

Tingginya angka pengguna twitter ini mempunyai implikasi yang tidak tunggal dan tidak hanya selingkup pada teknologi komunikasi dunia maya. Lebih jauh, dampaknya menerpa bidang ekonomi, sosial, budaya, bahkan politik.

Media sosial termasuk twitter, ternyata dapat menjadi tumpuan semangat membangun sistem politik, sosial, ekonomi, perdagangan yang mampu menggerakkan rakyat banyak mencari alternatif di tengah perilaku elite politik yang dirasa tidak demokratis. Dalam hal ini adalah para pemimpin negara yang dilihat mementingkan diri atau golongan sendiri dan mengebelakangkan kepentingan rakyatnya.

Bukti nyata peran besar twitter dalam dunia politik adalah gejolak politik dan sosial di kawasan Timur Tengah yang melanda seluruh negara Arab. Rakyat terpanggil dan tersatukan haluan serta geraknya melalui jejaring sosial digital untuk menentukan jalannya masa depan negara mereka.

Revolusi, yang terjadi di Mesir dan Tunisia, serta masih bergejolak di beberapa negara Timur
Tengah lainnya, mau tidak mau harus diakui menunjukkan keperkasaan media sosial. Twitter, yang jumlah penggunanya terus meningkat dari tahun ke tahun merupakan salah satu bagian media sosial yang ambil bagian dalam menghasilkan gerakan massa untuk menggulingkan rezim yang dipandang diktator tersebut. Dapat dikatakan bahwa gerakan massa dengan kontribusi twitter didalamnya, yang terjadi di Mesir dan Tunisia, merupakan gerakan massa jenis baru yang tidak bisa dipandang remeh.

Clay Shirky seorang Professor of New Media at New York University dan juga penulis "Cognitive Surplus: Creativity and Generosity in a Connected Age", juga mengatakan hal yang sama mengenai pengaruh besar media sosial terhadap kehidupan politik suatu Negara.

The use of social media tools - including social networking, - does not have a single preordained outcome. Therefore, attempts to outline their effects on political action are too often reduced to dueling anecdotes. If you regard the failure of the Belarusian protests to oust Lukashenko as paradigmatic, you will regard the Moldovan experience as an outlier, and vice versa. Empirical work on the subject is also hard to come by, in part because these tools are so new and in part because relevant examples are so rare. The safest characterization of recent quantitative attempts to answer the question, Do digital tools enhance democracy? (such as those by Jacob Groshek and Philip Howard) is that these tools probably do not hurt in the short run and might help in the long run - and that they have the most dramatic effects in states where a public sphere already constrains the actions of the government. (Shirky, 2011)

Selama ini, kebanyakan penelitian efek media memfokuskan kajiannya pada peran media dalam menghasilkan efek negatif - misalnya kekerasan yang menyatakan bahwa terpaan media adalah variabel utama yang berkontribusi terhadap efek tersebut (Young \& Rogers dalam Kim, 2009: 988). Karenanya, jangan sampai kondisi ini juga dipandang dalam kacamata yang negatif. Berbagai penelitian perlu dikembangkan untuk memperkaya khasanah ilmu yang berkaitan 
dengan penggunaan internet dalam perilaku komunikasi manusia.

Mengambil analogi dari Cultivation Theory yang dikemukakan George Gerbner, efek media sosial yang begitu kuat terhadap pandangan bahkan juga perilaku seseorang terhadap dinamika politik di negaranya akan sangat mungkin berkaitan dengan seberapa banyak waktu yang diluangkan oleh orang tersebut untuk terlibat dalam komunikasi di dunia maya.

Sebuah penelitian berjudul "The Role of Internet User Characteristics and Motives in Explaining Three Dimensions of Internet Addiction" yang dilakukan oleh Junghyun Kim dan Paul M. Haridakis dari Kent State University menyatakan bahwa seseorang dapat disebut sebagai pengguna berat internat adalah mereka yang menghabiskan waktunya lebih dari 194 menit (kurang lebih 3 jam) dalam sehari untuk mengakses internet (Kim \& Haridakis, 2009). Lebih lanjut, Kubey dalam Junghyun dan Kim (2009) juga menyebutkan bahwa mereka yang menghabiskan banyak waktunya untuk berinternet akan melibatkan diri mereka pada berbagai aktivitas yang berhubungan dengan internet, termasuk melibatkan emosi dan perasaan mereka.

Salah satu topik yang banyak diperbincangkan para tweeps (sebutan untuk pengguna twitter) Indonesia adalah tentang situasi politik negara ini. Seperti yang dikatakan oleh E. Prastowo, salah seorang praktisi media digital yang juga pengamat perbincangan twitter, orang-orang yang dalam kesehariannya tidak terlihat senang dengan masalah politik dalam negeri pun akan sangat aktif mengomentari posting-an atau meramaikan "kicauan" politik yang diperbincangkan di twitter. (Prastowo, 2011).

Melihat kenyataan ini, penting sekali bagi ilmu komunikasi untuk meneliti seperti apa realitas politik Indonesia pada pengguna berat internet. Dalam hal ini pendeskripsian dapat dilakukan dengan menggunakan asumsi-asumsi yang ada dalam teori kultivasi dari Gerbner. Meski teori kultivasi merupakan teori yang melandaskan asumsinya pada perilaku penonton televisi, namun beberapa penelitian menggunakan teori ini juga dapat dilakukan terhadap internet sebagai media baru. Salah satu contoh penelitian tersebut berjudul "Virtual Cultivation: Online Worlds, Offline Perceptions" yang dilakukan oleh Dmitri Williams, dari Department of Speech Communication, University of Illinois at Urbana-Champaign (Williams, 2006). Dia meneliti tentang persepsi penggemar game-game online terhadap realitas kehidupan mereka.

Berdasarkan latar belakang yang telah dipaparkan, salah satu pertanyaan menarik yang perlu dicari jawabannya adalah "Bagaimana realitas politik Indonesia pada pengguna twitter?", lebih khusus lagi adalah pada bagaimana pengguna berat dan pengguna ringan twitter memandang kondisi politik Indonesia. Jawaban atas pertanyaan tersebut diharapkan dapat menjadi masukan yang akan memperkaya kajian tentang media sosial dan kaitannya dengan partisipasi politik.

\section{METODE PENELITIAN}

Metode yang digunakan dalam penelitian ini adalah metode deskriptif, yang berusaha untuk memaparkan gambaran kondisi politik Indonesia dalam benak pengguna twitter, baik itu pengguna berat maupun ringan. Metode ini bertujuan untuk memaparkan data-data, yang kemudian dilakukan analisis terhadap data-data yang terkumpul dan tersusun tersebut.

Komponen yang akan diteliti adalah tingkat kepercayaan terhadap isu kondisi politik seperti yang diangkat oleh pengguna twitter, tingkat kepercayaan terhadap penyelesaian kasus korupsi di negeri ini, tingkat kepercayaan terhadap akun twitter para politikus, juga tingkat kepercayaan terhadap kondisi politik Indonesia ke depannya. Komponen-komponen tersebut akan dilihat persamaannya atau perbedaannya pada responden yang merupakan pengguna berat twitter dengan pengguna ringan.

Responden untuk penelitian ini adalah dua kategori pengguna internet, yaitu pengguna berat dan pengguna ringan. Berdasarkan angka dari Comscore Media Metrix (2011) yang menyebutkan jumlah pengguna internet dunia yang terbanyak adalah di rentang usia 15 hingga 21 tahun, maka informan penelitian ini adalah mahasiswa. Secara lebih khusus, mereka dipilih dari mahasiswa yang berkuliah di Institut Teknologi Bandung dan Universitas Padjadjaran. Salah satu faktor yang memperkuat pemilihan dua universitas terkemuka di Bandung ini ada- 
lah akses internet yang gratis dan begitu mudah di dua kampus ini. Sehingga mahasiswa-mahasiswanya relatif tidak mengalami hambatan dalam mengakses twitter.

Data dikumpulkan dengan menggunakan kuesioner yang disebar kepada responden dengan cara online, yaitu dengan dibuat menggunakan obsurvey.com. selanjutnya, tautan (link) dari survei ini dikirimkan kepada responden terpilih dengan menggunakan email dan layanan message pada twitter.

Dalam penelitian ini, yang dimaksud dengan kultivasi adalah proses yang terjadi karena pola berulang dari pesan-pesan dan kesan yang diproduksi massal dari perbincangan di twitter membentuk arus utama dari lingkungan simbolis umum (dibahasakan kembali dari Gerbner dalam McQuail, 1996: 254). Sementara itu, pengguna berat adalah orang-orang yang menghabiskan waktunya lebih dari 194 menit (kurang lebih 3 jam) dalam sehari untuk menggunakan internet (Kim \& Haridakis, 2009), dan pengguna ringan melihat pada definisi pengguna berat yang sudah dijelaskan di muka, adalah mereka yang menggunakan twitter kurang dari 3 jam sehari.

\section{HASIL DAN PEMBAHASAN}

Sebelum memaparkan hasil penelitian, penulis akan memaparkan karakteristik responden. Dari total 36 responden, lebih dari setengahnya menggunakan telepon pintar untuk mengakses akun twitter mereka. Jenis telepon pintar yang digunakan adalah Blackberry, iPhone, dan telepon berbasis Android. Selain itu 38,9\% responden menggunakan laptop untuk mengakses akun twitter mereka. Laptop masih relevan digunakan karena kompatibilitas yang masih memungkinkan untuk dibawa ke kampus, dimana responden biasa mengakses internet secara gratis menggunakan fasilitas wifi kampus mereka.

Hampir setengah responden mengikuti 100 hingga 200 akun, meski ada sebagian kecil yang kurang dari 100, dan ada pula yang pebih dari 200 bahkan hingga mencapai 500 akun.

Selanjutnya, lebih dari setengah responden mengikuti akun twitter seseorang yang khusus membahas isu politik, baik itu politikus maupun entertainer yang konsen pada isu politik Indonesia. Akun twitter yang paling banyak diikuti adalah@pandji, yang merupakan milik Pandji Pragiwaksono, seorang komedian yang biasa tampil di acara "Stand Up Comedy" di sebuah stasiun televisi swasta. Sebagian besar responden yang mengikuti@pandji mengaku bahwa mereka mengikuti akun itu bukan karena mengidolakan Pandji, namun hanya ingin mengetahui pemikirannya yang sering kali berbeda dan unik dibandingkan dengan pemikiran orang lain. Kadangkala mereka bahkan mengkritik balik pemikiran yang dilontarkan Pandji. Akun tokoh lain berkaitan politik yang diikuti adalah milik Tiffatul Sembiring, Menteri Komunikasi dan Informasi Kabinet Indonesia Bersatu II Republik Indonesia. Tiffatul memang memiliki daya tarik tersendiri untuk diikuti karena pernah memiliki kebiasaan tweet uniknya yang biasa "mengicaukan" pantun di setiap pagi hari. Selain itu, ada juga responden yang mengikuti akun milik Sujiwo Tedjo, Ulil Abshar, Hansdavidian, Angelina Sondakh, Indra J. Pilliang, Budiman Sudjatmiko, Wimar Witoelar, dan Anis Baswedan.

Hanya sebagian kecil saja dari responden yang mengikuti akun kanal berita atau media massa. Akun yang paling banyak diikuti adalah Detik, Metrotv, Kompas, The Jakarta Post, TVone, Antara, Viva, Jakarta Globe, Gresnews, dan Media Indonesia. Sebagian besar responden ternyata tidak mengikuti akun kanal berita atau media massa, dengan alasan berita bisa mereka dapatkan dengan mudah di media massa, seperti televisi, radio, dan koran. Alasan lainnya adalah responden dipusingkan dengan seringnya akun kanal berita men-tweet berita, sehingga memenuhi dan "menghalangi" responden untuk melihat status lain dari orang-orang "terdekat". Sebagian mereka dulu pernah mengikuti dan akhirnya menghentikan keikutsertaan mereka itu.

Dari sisi jumlah waktu mengakses twitter, responden yang tergolong pengguna ringan jauh lebih sedikit, yaitu 33,3\% yang mengakses twitter kurang dari tiga jam dalam sehari. Sementara lebih dari setengahnya, yaitu $66,7 \%$ adalah pengguna berat, mereka menghabiskan waktu lebih dari tiga jam dalam sehari untuk mengakses akun twitter.

Hampir setengah dari responden hanya kadangkala saja melihat berita atau isu politik Indonesia, yakni kasus-kasus besar saja seper- 
ti kasus "Nazaruddin", perhatian juga terutama mereka berikan pada kasus politik yang melibatkan public figure, seperti kasus "Angelina Sondakh". Esensi kasusnya juga mereka tidak terlalu paham, mereka hanya tahu nama tokoh yang diberitakan dan diisukan, sementara deskripsi kasusnya hanya mereka pahami sekilas. Selanjutnya $38,9 \%$ sering mengikuti, karena mereka senang menonton berita, dan berita di televisi nasional saat ini didominasi isu-isu politik negeri ini.

Hampir setengah responden masih mengandalkan media massa konvensional sebagai sumber utama berita atau isu politik Indonesia. Bahkan mereka yang menggunakan situs internet dan media sosial sebagai sumber berita, tetap saja mencari kevalidan berita yang mereka dapatkan dengan menonton televisi atau mencarinya di surat kabar.

Setelah memaparkan data responden, selanjutnya penulis akan memaparkan analisis hasil penelitian. Hampir setengah responden memandang kondisi politik Indonesia sama dengan yang ditampilkan di televisi. Menurut mereka televisi saat ini sudah kritis dalam melihat berbagai fenomena, selain itu tidak ada kekangan berarti dari pemerintah, hingga mereka dapat menyampaikan berita tentang kondisi politik Indonesia sebagaimana yang berhasil mereka liput. Meski, responden sadar bahwa setiap stasiun televisi memiliki sudut pandang yang tidak sama terhadap sebuah isu politik. Pemberitaan mereka dianggap hanya sebagian sama, tidak sepenuhnya sama karena bingkai berita setiap stasiun televisi sangat bergantung pada konstelasi politik yang melibatkan pemilik stasiun televisi tersebut.

Pesimistis akan penyelesaian kasus korupsi di Indonesia ternyata dirasakan oleh para responden, sebanyak hampir setengahnya memandang bahwa kasus korupsi tidak akan terselesaikan, bahkan $36,1 \%$ di antaranya menganggap kasus-kasus korupsi di Indonesia tidak akan pernah terselesaikan. Menurut responden, korupsi seperti sudah mendarah daging, belum lagi korupsi tersebut melibatkan berbagai elemen penguasa negeri yang seharusnya bertugas mengadilli para koruptor.

Penting untuk diketahui, ternyata hampir setengah responden ragu-ragu akan tingkat kepercayaan twitter dibandingkan dengan media massa konvensional. Kondisi ini terjadi karena komentar-komentar yang ada di twitter adalah pendapat-pendapat pribadi, terkadang sumber beritanya juga belum tentu dapat dipastikan kebenarannya. Kalaupun responden percaya, yang mereka percaya adalah berita yang diposting di twitter namun sumber pertama berita itu adalah situs berita atau kanal berita.

Sejalan dengan itu, lebih dari setengah responden ragu-ragu, tidak sepenuhnya percaya terhadap ucapan tokoh politik dan tokoh muda yang mereka ikuti twitternya. Mereka yang mengikuti akun twitter tokoh poitik mengaku bahwa mereka tidak mengidolakan para tokoh tersebut, mereka mengikuti untuk sekadar ingin tahu pandangan sang tokoh. Bahkan, terkadang mereka tak segan membantah bila punya pandangan yang berbeda.

Yang memprihatinkan, hampir setengah responden ternyata meragukan masa depan Indonesia bisa lebih baik dari saat ini. Menurut responden, masalah bangsa ini banyak yang sulit terselesaikan dengan sistem yang berjalan sekarang, misalnya kasus korupsi. Bila korupsi yang begitu besar dan jelas di depan mata tidak diselesaikan, maka pembangunan juga mereka rasa tidak akan berjalan lancar. Bagaimana akan membangun, bila dana milik negara hanya digunakan untuk kepentingan individu dan kelompok tertentu.

Bila diperbedakan pandangan antara pengguna berat dengan pengguna ringan, terlihat bahwa terdapat perbedaan persentase dari kedua golongan ini dalam melihat penyelesaian kasus korupsi di Indonesia. Namun berlawanan dengan asumsi awal yang memprediksi pengguna berat lebih negatif memandang penyelesaian kasus korupsi ini, data yang didapat justru menunjukkan bahwa pengguna akun twitter di bawah 3 jam justru memandang lebih negatif dibandingkan pengguna berat. Sebagian besar, lebih dari setengah responden pengguna ringan memandang kasus korupsi di Indonesia tidak akan pernah terselesaikan.

Demikian pula dengan pandangan terhadap masa depan Indonesia, Sebagian besar, lebih dari setengah responden pengguna ringan memandang ragu-ragu akan masa depan Indonesia yang lebih baik.

Ada beberapa penyebab fenomena ini, diantaranya adalah sumber utama berita baik peng- 
guna berat maupun pengguna ringan adalah sama, yaitu media massa konvensional, terutama televisi. Selain itu, mayoritas responden juga masih ragu akan keterpercayaan isu politik di twitter di bandingkan dengan di media massa.

Hasil penelitian ini justru memperkuat temuan apa yang disampaikan Gerbner dalam teori kultivasinya, bahwa televisi memiliki kekuatan dalam membentuk realitas (dalam McQuail, 1996). Dampak medium televisi melalui tayangan-tayangannya seputar politik di Indonesia mampu memengaruhi persepsi khalayak mengenai realitas politik Indonesia.

Kultivasi tidak terjadi pada pengguna twitter salah satunya dapat disebabkan oleh perbedaan karakteristik internet dibanding dengan media klasik dalamsistem dan operasional sebagai alat maupun media komunikasi, yakni: (1). Perbedaan utama dan makro yaitu; internet adalah media berbasis computer; (2). Internet sebagai media komunikasi memiliki penawaran interaktif yang dinamis terhadap penggunanya/user; (3). Media internet mampu menjadi pusat informasi dan sumber informasi yang tidak terbatas; (4). Luas jangkauan dari media internet tentu saja melintas antarbenua, antarnegara, serta antarbudaya; dan (5). fungsi internet sebagai media, selain sama dengan fungsi media lain, media internet memiliki penawaran untuk pengembangan bidang jasa maupun bisnis sebagai bagian gaya hidup (Sosiawan, 2000: 1).

\section{SIMPULAN}

Simpulan dari penelitian ini adalah pengguna berat memandang pesimis pada berbagai kondisi politik di Indonesia, hal ini terlihat diantaranya dari ketidakpercayaan mereka pada penyelesaian kasus korupsi di Indonesia, juga masih adanya keragu-raguan mereka akan masa depan Indonesia yang lebih baik. Sementara itu, penelitian ini menghasilkan data tentang pengguna ringan yang berbeda dengan asumsi awal penelitian. Dalam asumsi teori kultivasi, pengguna ringan akan lebih positif memandang realitas. Namun hasilnya tidak demikian, hal ini terlihat dari pandangan sebagian besar mereka yang meragukan masa depan Indonesia yang lebih baik, juga sebagian besar mereka menganggap kasus korupsi di Indonesia tidak akan pernah terselesaikan.

Beberapa kondisi yang menyebabkan tidak signifikannya perbedaan pandangan antara pengguna berat dan ringan twitter adalah sumber utama berita baik pengguna berat maupun pengguna ringan adalah sama, yaitu media massa konvensional, terutama televisi. Selain itu, mayoritas responden juga masih ragu akan keterpercayaan isu politik di twitter di bandingkan dengan di media massa.

Hasil penelitian ini yang menunjukkan bahwa pandangan rakyat Indonesia tentang kondisi politik Indonesia yang masih sangat dipengaruhi oleh media massa konvensional hendaknya menjadi masukan bagi para praktisi media untuk menjadikan televisi sebagai penggerak ke arah Indonesia yang lebih baik. Diantaranya, dengan merancang program-program yang berisi pemberian semangat atau optimisme tentang masa depan Indonesia, termasuk kondisi politik Indonesia ke depan yang akan lebih baik dengan partisipasi generasi muda.

\section{DAFTAR PUSTAKA}

Comscore Media Metrix. (2011). Diakses tanggal 5 Juli 2011 melalui http://www.comscore. com/Press Events/Press Releases/2011/4/ The Netherlands Ranks numberone Worldwide in Penetration for Twitter and LinkedIn

Kim, J. \& Haridakis, P. M. (2009). The role of internet user characteristics and motives in explaining three dimensions of internet addiction. Journal of Computer-Mediated Communication, 14, 988-1015.

McQuail, D. (1996). Teori komunikasi massa. Jakarta: Penerbit Erlangga.

Prastowo, E. (2011). Facebook dan twitter jadi mata amerika. Diakses tanggal 5 Juli 2011 melalui http://politik.kompasiana. com/2011/02/22/facebook-dan-twitter-jadi-mata-amerika/

Shirky, C. (2011). The political power of social media: technology, the public sphere, and political change. Diakses tanggal 5 Juli 2011 melalui http://www.yuswohady.com/ wp-content/uploads/2011/01/The-PoliticalPower-of-Social-Media-Clay-Sirky-ForeignAffairs.pdf

Sosiawan, E. A. (2000). Kajian internet se- 
bagai media komunikasi interpersonal dan massa.Diakses tanggal 5 Juli 2011 melalui http://edwi.dosen.upnyk.ac.id/Internet $\% 20$ as $\% 20$ media.pdf
Williams, D. (2006). Virtual cultivation: online worlds, offline perceptions. Journal of Communication, 56, 69-87 